\title{
The Development of Simple Harmonic Vibration Student Learning Worksheet (LKPD) based on Curious Note Program (CNP) Learning Model in Improving Students' Creative Thinking Ability
}

\author{
F P Farumananda ${ }^{1}$, Wiyanto ${ }^{2}$, and N M D Putra ${ }^{3}$ \\ ${ }^{1,2,3}$ Graduate School, Universitas Negeri Semarang, Semarang, Indonesia \\ ${ }^{1}$ Corresponding email: fatimahprimadian1404@gmail.com
}

\begin{abstract}
This research aims to analyze the feasibility, praticality, and effectiveness of Simple Harmonic Vibration student learning worksheet (LKPD) based on Curious Note Program (CNP) learning model which can improve the students' creative thinking ability. The research was categorized as Reasearch and Development (R\&D) study which refers to a model 4-D. The data were collected by using sheet questionnaire of syllabus validation, lesson plan (RPP) validation, student learning worksheet (LKPD) validation, questionnaires test, teacher and students' questionnaire response to student learning worksheet, and the interviews result of the teacher and students to student learning worksheet. The subjects of this research were media expert lecturer, subject expert lecturer, physics education teacher, and students of grade $\mathrm{X}$ at MA Negeri Temanggung in 2017/2018 academic year. The result of this research shows that the syllabus, lesson plan (RPP), and student learning worksheet (LKPD) based on Curious Note Program (CNP) learning model is feasible and effective to use in Physics education learning process especially on the simple harmonic vibration learning topic which is shown by validator score obtained $91 \%, 90 \%$, and $91 \%$ as a valid category. Besides, the effectiveness of enhancing the students' creative thinking ability using simple harmonic vibration LKPD based on Curious Note Program (CNP) model is shown with N-Gain value of 0.83 as high category and educator and student response questionnaire of $83 \%$ and $80 \%$ as hing one, as well.
\end{abstract}

Keywords: development, learning model, CNP, creative thinking ability

\section{Introduction}

Education is inseparable from human life and developing era. Education will also continue to evolve over time. Learning is a process to go better. In this era of globalization as it is now, the demands of quality education is increasing (Mergendoller et al., 2006). The problems that arise in the world of education become a demand for teachers to adjust their learning (Davis, 2003). Therefore, a teacher constantly strives to adapt his/her learning to a constantly changing academic standard. All efforts made by the teacher will ultimately produce superior generations in various aspects which consist of cognitive, affective, and psychomotor aspects. In addition to the role of teachers, quality education also involves the role of learners to actively learn, and to achieve that quality, learning activities need principles which are: (1) learning centered on learners, (2) develop creativity of learners, (3) create fun learning conditions, (4) having value, ethics, aesthetics, logic and kinesthetic, (5) applying various strategies and learning methods (Hosnan, 2014).

In accordance with the principles used to achieve quality education, of course, there is also needed a creativity to face global changes as well as the demands of scientific and technological progress. This means that someone who has creativity will be able to face the development of science and technology. One of the most important developments in education is the development of Physics Education (Lazzaro, 2015). Creativity has become a major attention in education in Europe, America, Australia and East Asian countries (Shaheen, 2010). Creativity in the context of science must be able to reflect the scientific idea that will be visible when learners can act like a scientist in the learning atmosphere. Appropriate activities to foster scientific creativity in education include: (1) giving students the opportunity to think imaginatively; and (2) cultivating perceived experience (Hadzigeorgiou, et al., 2012)

Creative thinking is a product of creativity. In addition, the ability to think creatively is one of the important abilities of the 21st century, learners must acquire and use it (Rahmawati and Sugianto, 2016). The ability to think creatively is also the embodiment of higher-order thinking which is a process of thinking that is not to just memorize and relay information that is known. Also, Regulation of 
the Minister of Education and Culture number $81 \mathrm{~A}$ on Curriculum Implementation describes the learners' ability needed in learning are communication skills, critical and creative thinking (Kemendikbud, 2013). This shows that the ability to think creatively is important in the learning of physics.

The facts of the situation shows that the learning activities have not run as desired to achieve a quality education and improve students' creative thinking ability. This is demonstrated by student learning worksheet (LKPD) used by the learners did not used properly by the teacher, although there are steps in student learning worksheet (LKPD) to assist learners in thinking creatively but the steps itself did not used by teachers. So, by looking at technological advances today, teachers prefer to use Power Point in learning activities instead of student learning worksheet (LKPD) in which it is finally used to be questionnaires test only. It certainly doesn't help the learners to think creatively because it is still focused on physical concepts that are identical with mathematical equations and learners tend to be passive and less able to understand the material significantly. In addition, the learning model used also does not support learners to think creatively. Therefore, it requires learning centered on learners and can develop creative thinking ability of learners.

Temur says that there is a learning model needed that can involve learners in collaboration in a group to share ideas during the process of creative thinking (Temur, 2012). One of the learning models that supposedly can do to develop creative thinking ability is model learning Curious Note Program (CNP). This learning model was developed by Jongsoek Park, Yohan Hwang, Eunju Park and Jaeheon Park by combining various types of independent inquiry (Autonomic Inquiry) with Integrated Process Skills and Science Writting Heuristic (Park et al., 2009).

The ease in applying the CNP learning model is assisted by using learning tools in the form of student learning worksheet. The facts on the field show that student learning worksheet provided can not be used to develop students' creative thinking ability.

\section{Methods}

This research is a research and development (R \& D) 4-D model according to Thiagarajan and Semmel (1974). This research developed student learning worksheet based on CNP learning model on simple harmonic vibration to improve students' creative thinking ability. The tools produced included the syllabus, the lesson plan (RPP), the student learning worksheet (LKPD), and questionnaires test of creative thinking ability. This research procedure involved stages of Defining; Designing; Developing; and Disseminating. The results of this study were not disseminated to other classes or other schools (other than research sites) so that this study used only three stages which embraced Defining; Designing; and Developing. In the Defining stage, there were five basic steps; need analysis, student analysis, task analysis, concept analysis, and the formulation of learning objectives. Furthermore, at the designing stage, researcher began to compile syllabus, lesson plan (RPP), student learning worksheet (LKPD), and observation sheet which then were validated by two experts and school teachers where the research was conducted. Lesson plans (RPP) and student learning worksheet (LKPD) were developed in accordance with the CNP-based learning model. Development stage was done by improving lesson plan (RPP) and student learning worksheet (LKPD) in accordance with validator suggestion and limited trial result. Improved lesson plan (RPP) and student learning worksheet (LKPD) were then piloted in the designated classes.

The validation results of lesson plan (RPP) and student learning worksheet (LKPD) from experts were tested using One Group Pretest Posttest Design method (Sugiyono, 2010). The research subjects were X MIA 3 in MAN Temanggung year 2017/2018. Trial was conducted to obtain information in the form of learning implementation, students' creative thinking ability, and the response of educators and learners. Trial instrument was in the form of observation sheet of learning implementation, description sheet of creative thinking ability, questionnaire response of educator and learner, and interview.

The data obtained were analyzed descriptively quantitative and qualitative. The data produced was initially in the form of 
quantitative data analysis. Then the results of data analysis were described using qualitative descriptive analysis to obtain statements that described the categories of the numbers and interviews obtained. The effect of learning on students' creative thinking ability can be found by using the normalized gain formula according to Hake (1999) as follows.

$$
\langle g\rangle=\frac{S_{\text {postest }}-S_{\text {pretest }}}{100 \%-S_{\text {pretest }}}
$$

\section{Results and Discussion}

\subsection{The Validity}

This research is a research of student learning worksheet development based on Curious Note Program (CNP) model on simple harmonic vibration which aims to improve students' creative thinking ability. Learning devices can be declared feasible if aspects of validity, practicality, and effectiveness are met (Nieeven, and Plomp, 2007). Learning tools that have been developed in the form of syllabus, lesson plan (RPP), student learning worksheet (LKPD), as well as questionnaires test of creative thinking ability. The tool developed is adapted to the Curious Note Program (CNP) learning model.

Based on the research data, the feasibility of the learning instrument is viewed from the validation result of the device by two experts and the school teacher which cover syllabus, lesson plan (RPP), student learning worksheet (LKPD), and questionnaires test of students' creative thinking ability. Practicality of lesson plan (RPP) and student learning worksheet (LKPD) are viewed from the implementation of the lesson plan (RPP). The effectiveness of lesson plan (RPP) and student learning worksheet (LKPD) are viewed from the questionnaire tests (pretest and postest) results of the students' creative thinking ability, responses from educators and learners, and the results of interviews.

Syllabus, lesson plan (RPP), student learning worksheet (LKPD), and questionnaires test of creative thinking ability that have been developed then validated by three validators. In general, the syllabus, plan (RPP), student learning worksheet (LKPD), and questionnaires test developed is to obtain valid results from the validator. The syllabus developed by the researcher is a syllabus based on Curious Note Program (CNP) model on simple harmonic vibration. Syllabus is a set of plans and arrangements regarding learning activities, classroom management, and assessment of learning outcomes (Kardi, 2013). Supeno (2016) states that a good syllabus can be used as a reference for composing the framework of learning. The learning framework in the next syllabus was developed in the form of lesson plan (RPP) and student learning worksheet (LKPD). The statement indicates that the syllabus is the basis used as a reference in developing lesson plan (RPP) and student learning worksheet (LKPD). Therefore, the developed syllabus must be categorized as valid.

Validation results of the syllabus by the validator show that the syllabus component got an average score of 4.7 with a very valid category with an average validity of $94 \%$. The syllabus is valid because the components met with the syllabus, such as the identity of the learning subject, the school identity, the competency standard, the basic competence, the indicator, the learning material, the learning kejaan, the assessment, the time allocation, and the learning resources (Permendikbud No. 58 of 2014).

The RPP developed in this study is also an RPP based Curious Note Program (CNP) learning model on simple harmonic vibration. The learning activities put in the RPP are adapted to the CNP learning model syntax. The developed RPP was validated by three validators before it was implemented. The RPP validation results show that the developed RPP can be used in the pilot phase. This is because the average RPP validation assessment is $90 \%$. Regulation of the Minister of Education and Culture number 58 year 2014 states that in the preparation of the RPP should contain indicator and learning objectives, description of teaching materials, the elaboration of learning activities, learning methods, determining the allocation of time, tools and learning resources and development of learning results. Learning that has been done in the classroom or outside the classroom should be able to cultivate the students' creative thinking ability.

The developed LKPD was aiming to trace students' creative thinking ability in designing investigation activities and summarizing the findings of the investigation. The LKPD validation indicates that the developed LKPD 
is valid in use at the pilot phase with an average LKPD validation rating on the format, language and content component of $91 \%$. The validator provides suggestions for improving the LKPD used in the trial. Advice from this validator is used as a reference by researcher to revise LKPD to be used. LKPD used consists of two types of LKPD. LKPD includes the level of creative thinking ability of learners. the goal is that learners can improve their creative thinking ability through working together in groups and presented in front of the class in order to get feedback from other friends.

Instrument questionnaires test of creative thinking ability of learners that have been developed can be declared valid and can be implemented. This is evidenced by the acquisition of validation results of the instrument scored $86 \%$ categorized very valid.

\subsection{Practicality}

The practicality of syllabus, RPP and LKPD developed viewed from the implementation of the lesson plan (RPP). This is visible based on the observation result of 3 observers. At the first meeting is maximum already. However, at the second meeting seemed less than the maximum. This happens because the time required is still less. This is evidenced from the assessment provided by observers. After the evaluation, at the next meeting the researcher rectify the deficiencies that occur so that the average score of learning implementation in class X on LKPD 1 and LKPD 2 is 4.07 and 4.02 with a very good category with an average percentage of $80.92 \%$, so overall learning activities listed in the RPP can be done well.

The developed RPP refers to instructional-oriented learning, so almost all activities are good with an average percentage of $80.92 \%$, so that overall learning activities listed in the lesson plan can be done well.

RPP that has been developed refers to learning-oriented learners,, so that almost all learning activities centered on learners, which are learners can find the problem of an object, then create a trial design through discussion in groups. All the activities in LKPD are in accordance with the progressive educational philosophy developed by Jhon Dewey stating that education is student-centered (Ornstein and Levine, 1985).
This Curious Note Program (CNP) learning model is suitable to be able to practice creative thinking ability of learners as one of its advantages related to the daily life of the learners. This will encourage learners to be more sensitive to the problems that occur around them.

\subsection{Effectiveness}

The learning process using LKPD based on Curious Note Program (CNP) learning model on simple harmonic vibration runs well and can be said to be effective. The effectiveness of LKPD developed viewed from the improvement of students' creative thinking ability during the pretest and posttest.

The provision of LKPD that was developed turned out to affect the effectiveness of learning. This is evidenced by an increase in the creative thinking ability of learners on the trials test against 40 students of class X MIA 3 MAN Temanggung. The test of creative thinking ability of the students of class X MIA 3 at the time of pretest was obtained on average 13.1 with an incomplete category, this happened because some of the students still had difficulties when working on a question that demanded variation of answer or ability to generate many ideas. The posttest obtained an average of 49.9 and stated learners have increased in the ability of creative thinking. This is due to the learning that gives the learners the opportunity to learn for themselves in the group so as to provide wide space for learners to express ideas / ideas in the learning process.

The N-gain calculation shows an average of 0.83 with high category, this is because the $\mathrm{N}$-Gain score is in the range of $0.70 \leq \mathrm{g} \leq 1$ which belongs to the high category, although the researcher feels new to the learning method and the previous lesson does not emphasize students' creative thinking ability, however, the results show that Curious Note Program (CNP) -based learning model on simple harmonic vibration can improve the creative thinking ability of learners.

The response of educator and learner to LKPD based on Curious Note Program (CNP) model on simple harmonic vibration looks positive, it is proved by questionnaire of educator response shows $83 \%$ score and 90.13\% students with high category then the 
data is matched with interview results stating that educators are interested in applying this method to other subjects whereas learners argue that learning activities using LKPD based on this CNP learning model can change the learning atmosphere to be fun and learners more easily understand the material being taught.

\section{Conclusion}

Based on the result of the research, it can be concluded that LKPD based on Curious Note Program (CNP) learning model on simple harmonic vibration developed are feasible and practical to be used for learning and effective activities to improve the creative thinking ability of learners.

\section{References}

Davis, K. S. (2003). Sci. Edu. 87(1), 25-30.

Hadzigeorgiou, Yannis, Persa Fokialis, and Mary Kabouropoulou. (2012). Sci. Ressearch 3(5), 603-611.

Hake, R. R. (1999). Analyzing change/gain scores. Woodland Hills, CA: AERA-D

Hosnan. (2014). Pendekatan Saintifik dan Kontekstual dalam Pembelajaran Abad 21. Bogor: Ghalia Indonesia.

Kardi, S. (2013). Pengantar Pengembangan Kurikulum \& Rencana Pelaksanaan Pembelajaran. Surabaya: Universitas Negeri Surabaya.

Kemdikbud. (2013). Permendikbud 81A tahun 2013 tentang Implementasi Kurikulum 2013. Jakarta: Kementrian Pendidikan dan Kebudayaan.

Lazzaro, Christopher. (2015). On the Consideration of Adaption and Implementation of the Next Generation Science Standars in a Local-Control Context: Supporting the Epistemology of Science through Education Policy. Disertasi. United States: Columbia University.
Mergendoller, J., Markham, T., Ravitz, J., and Larmer, J. (2006). Handbook of classroom management: Research, practice, and contemporary issues. Mahwah, NJ: Lawrence Erlbaum. 583615.

Nieeven, N. dan Plomp, T. (2007). Formative Evaluation in Educational Design Research. (Enschede: Netherlands Institute for Curriculum Development).

Ornstein, Allan C \& Levine, Daniel U. (1985). An Introduction to The Foundation of Education. Boston: Houghton Mifflin Company.

Park J., Hwang, Y., Park, E. \& Park, J. (2009). Proc. Int. Sci. Edu. Conference (ISEC). Singapore: National Institute of Singapore. 1512.

Peraturan Menteri Pendidikan dan Kebudayaan Republik Indonesia Nomer 58 Tahun 2014. Pembelajaran Pada Pendidikan Dasar dan Pendidikan Menengah. (Jakarta : Menteri Pendidikan Nasional).

Rahmawati, N.T. \& Sugianto. (2016). Unnes. J. Math. Reseach. UJMER. 5(1).

Shaheen, Robina. (2010). J. Creative. Edu. 1(3). 166-169.

Sugiyono. (2010). Metode Penelitian Kuantitatif Kualitatif dan $R \& D$. .Bandung: Alfabeta.

Supeno. (2016). Model Pembelajaran Penyelesaian Masalah Argumentatif untuk Meningkatkan Hasil Belajar Fisika Kognitif Produk, Ketrampilan Proses Sains, \& Argumentasi Ilmiah Siswa SMK. Disertasi.(Surabaya: Universitas Negeri Surabaya).

Temur, Ozlem Dogan. (2012). Eurasia. J. Math, Sci \& Technol Edu, (8)2, 83-93.

Thiagarajan, S., Semmel, D.S. \& Semmel, M.I. (1974). Instructional Development for Training Teachers of Exiceptional Children: A Sourcebook. Indiana: Indiana University. 